Western University

Scholarship@Western

Education Publications

Education Faculty

2014

Researching Neoliberal and Neocolonial Assemblages in Early Childhood Education

Veronica Pacini-Ketchabaw

vpacinik@uwo.ca

Fikile Nxumalo

University of Texas at Austin

Mary Caroline Rowan

Concordia University, Montreal, Quebec, Canada

Follow this and additional works at: https://ir.lib.uwo.ca/edupub

Part of the Early Childhood Education Commons

Citation of this paper:

Pacini-Ketchabaw, Veronica; Nxumalo, Fikile; and Rowan, Mary Caroline, "Researching Neoliberal and Neocolonial Assemblages in Early Childhood Education" (2014). Education Publications. 39.

https://ir.lib.uwo.ca/edupub/39 


\title{
Researching Neoliberal and Neocolonial Assemblages in Early Childhood Education
}

\author{
Veronica Pacini-Ketchabaw, Fikile Nxumalo, \\ and Mary Caroline Rowan
}

\begin{abstract}
The article provides a discussion of "researching" neoliberalisms and neocolonialisms in white settler colonial societies such as Canada. It addresses the research implications after conceptualizing neoliberalisms as assemblages that are always already implicated in colonial histories. Specifically, the article discusses the need to rethink methodologies when neoliberalisms do not follow coherent directions, the kinds of methodological and research approaches necessary for the fluid and nonlinear movements of neoliberalisms and neocolonialisms, and how neoliberalisms and neocolonialisms as connected assemblages open up early childhood research practices that attend to colonial pastpresents.
\end{abstract}

With other authors in this special issue, we have been attending to the complexities and dangers of neoliberalism in early childhood education (Nxumalo, PaciniKetchabaw, \& Rowan, 2011). Our interest is to examine the enactment and deployment of early childhood education policies and practices, specifically how everyday early childhood practices (and policies that inform these practices) come to matter as instances of neoliberal acts that merge with other discursive and material forces to create particular, situated neoliberal assemblages that have colonizing effects on the capacities of certain bodies in certain spaces. We are interested in recent "transformation" movements within early childhood education and how these movements (although they appear quite progressive) become part of flexible and malleable neoliberal assemblages. These conceptualizations of neoliberalisms, coupled with neocolonialisms, have implications for how research is conducted in early childhood education. How do we think about methods and methodologies when neoliberalisms do not specifically follow coherent directions? What kinds of methodologies and research approaches are necessary for the fluid and nonlinear movements of neoliberalisms and neocolonialisms? How might neoliberalisms and neocolonialisms as

International Review of Qualitative Research, Vol. 7, No. I, Spring 2014, pp. 39-57.

ISSN 1940-8447, eISSN 1940-8455. (c) 2014 International Institute for Qualitative Research,

University of Illinois, Urbana-Champaign. All rights reserved. Request permission to photocopy or

reproduce article content at the University of California Press's Rights and Permissions website at

http://www.ucpressjournals.com/reprintinfo.asp. DOI: 10.1525/irqr.2014.7.1.39. 
connected assemblages allow us to rethink and open up early childhood research practices that attempt to pay attention to colonial pastpresents?

This paper provides a discussion of "researching" neoliberalisms in early childhood education. We begin by providing a brief overview of how we conceptualize neoliberal assemblages. Then, we address movements in qualitative research methodologies that help us to engage in "researching" neoliberalisms as assemblages. The final section of the paper describes how we have engaged in researching neoliberal assemblages with an emphasis on neocolonialisms. We weave in four examples of how we have approached "researching" neoliberal neocolonial assemblages in early childhood education. In the paper, we suggest that the subtleties, complexities, and multiplicities of neoliberalism as well as its entanglements with neocolonialisms necessitate creative methodological approaches, approaches that engage with politically and ethically related questions and that work with the tensions that decolonization brings.

We are focusing on what is today called Canada, as a geopolitical location. Canada is a settler colonial space that was violently taken from Indigenous peoples by European colonizers. The colonial project in North America that began hundreds of years ago continues to this day. Indigenous peoples continue to suffer the devastating consequences of decades of imperial practices and policies that used tools such as education to colonize. These tools forced Indigenous peoples from their lands onto reservations, disintegrated families, and stripped their languages and knowledges (Battiste \& Henderson, 2000). These colonialist legacies form part of our everyday practices as the colonial past inhabits all local presents. In addition, although there might be an "official recognition of Canada as a diverse society" because of its adoption of a multiculturalism policy in the early 1970s, "the normative vision of Canada as a white man's country is still pervasive" (Baldwin, Cameron \& Kobayashi, 2011, p. 4). As Baldwin, Cameron, and Kobayashi (2011) note, "despite liberal assurances to the contrary, Canada is a polity whose juridical-political structure, history, spatial arrangements, and social relations are thoroughly racialized and marked by racist ideologies" (p. 8).

By outlining possible theoretical and methodological frameworks, we are not attempting to solve the large debate around the conceptualization of neoliberalism and its methodological implications (see Collier, 2012; Kalb, 2012; and Peck \& Theodore, 2012, for examples of this debate). We come to this endeavor with an awareness of the messiness of neoliberalisms and therefore knowing the impossibility of providing a definitive conception of the term. Our hope is to engage with the messiness of neoliberalisms and neocolonialisms and, in turn, to engage in challenging the colonial 
histories of early childhood education. We tap into the large literature on neoliberalism and think about neoliberalisms as forming assemblages that continually capture and recapture early childhood practices and, in turn, transform those assemblages.

\section{Neoliberal Assemblages}

The focus of our work has been the investigation of early childhood neoliberal assemblages. We are interested in identifying key elements of these assemblages, their shifting linkages or interconnections, and the multitudinous effects produced by the intermingling of these elements within the geopolitical contexts of Canada and the broader context of the forces of neoliberalism, neocolonialism, and globalization. By conceptualizing neoliberalisms as assemblages, we seek to avoid generalized explanations of neoliberalism as an overarching system or machinic totality that simply shapes subjects:

In broad terms, assemblage is, then, part of a more general reconstitution of the social that seeks to blur divisions of social-material, near-far and structureagency. In this use, deploying the term assemblage enables us to remain deliberately open as to the form of the unity, its durability, the types of relations and the human and non-human elements involved. Indeed, we could understand the contemporary enthusiasm for assemblage theory as a response to ambivalence toward the a priori reduction of social-spatial relations and processes to any fixed form or set of fixed forms. (Anderson \& McFarlane, 2011, p. 124)

We seek to create disruptions in a totalitarian conceptualization of neoliberalism by confronting neoliberalisms on their slippery territory. Furthermore, we employ the term assemblage "to understand assembling as a process of 'co-functioning' whereby heterogeneous elements come together in a non-homogeneous grouping" (Anderson \& McFarlane, 2011, p. 125). We also draw on Deleuze and Guattari's (1987) understanding of assemblages to emphasize a conception of neoliberalism as material-discursive forces (Ong, 2007), where these forces and the relations between them comprise

lines of articulation or segmentarity, strata and territories; but also lines of flight, movements of deterritorialization and destratification. Comparative rates of flow on these lines produce phenomena of relative slowness and viscosity, or, on the contrary, of acceleration and rupture. All this, lines and measurable speeds, constitutes an assemblage. (Deleuze \& Guattari, 1987, pp. 3-4) 
The elements and effects of particular arrangements and locations of an assemblage are emergent, fluid, and mobile (Hier, 2003; Ong, 2007). Conceptualizing an assemblage as emergent means to think of it as existing in tension. The concept of assemblage allows us to describe some of the multiple and at times incongruent connections between the shifting social, economic, political, and material forces that come together in the emergence of geopolitically and temporally situated formations of early childhood governance and surveillance.

Our emphasis on assemblages also points to a conceptualization of neoliberalisms as contingent, contradictory, complex, and deviating multidirectional processes that shape individual desirable subjectivities (Ong, 2007; Peck \& Theodore, 2012; Ren, 2005). In other words, neoliberalisms possess repeated attributes that provide some unity or coherence, including the privileging of "self-discipline, self-rationalization, self-responsibility, and self-development" (Ren, 2005, para. 19). However, these and other attributes contingently emerge together in unstable, incomplete, and contradictory assemblages that include "extreme dynamism, mobility of practice, responsiveness to contingencies and strategic entanglements with politics" (Ong, 2007, p. 3). This suggests movement away from oppositional politics and toward inhabiting what neoliberalisms $d o$, what effects they produce, "and the dividing practices they promote in materializing particular worlds" (Edwards, 2012, p. 525). Emergent neoliberal assemblages include the strengthening or coagulation of mutually constitutive forces and desires that give rise to, and sustain, neoliberal surveillance and governance, such as the desire for control as well as potentials for disruption of surveillant forces (Haggerty \& Ericson, 2000).

\section{Reimagining Methods and Methodologies}

Researching neoliberalisms can pose challenges when thinking about these terms as assemblages. How do we even engage with the slipperiness of neoliberalisms? McCoy (2012) notes:

Neo-liberal logics and practices ... provide regulatory regimes, conceptual and material pathways to channel and limit certain ways of working with complexity in qualitative research, especially those that choke the flow by not providing the kind of evidence required to keep the whole thing moving or that challenge supposed "common sense" ways of reading the world. (p. 762)

To begin to engage with these complexities, we have found useful the work of scholars who rethink dominant approaches to qualitative research, destabilize the 
representational aspects of methodologies, and pay attention to complexities in research (e.g., Koro-Ljungberg \& Mazzei, 2012; Law, 2004; MacLure, 2010; Mazzei \& McCoy, 2010; Mol, 2002). For example, Koro-Ljungberg and Mazzei (2012) argue that researchers need to ask what is lost "when scholars and policy makers demand, perform, and build on (over)simplified knowledge claims" (p. 728). Law (2004) says the following about research methods:

If 'research methods' are allowed to claim methodological hegemony or (even worse) monopoly, and I think that there are locations where they try to do this, then when we are put into relation with such methods we are being placed, however rebelliously, in a set of constraining normative blinkers. We are being told how we must see and what we must do when we investigate. And the rules imposed on us carry, we need to note, a set of contingent and historically specific Euro-American assumptions. (p. 4)

Law continues to argue that the conceptualization of procedures and rules as essential and sufficient to research processes must be reconsidered when studying the "ephemeral, the indefinite and the irregular" (p. 4). In his critique, Law argues that research has rendered invisible the "authorship, the uncertainties, the enactment of out-thereness" (p. 88) of what research is about. He writes:

Overall, the social is taken to be fairly definite. Such is the framing assumption: that there are definite processes out there that are waiting to be discovered.... But this is precisely the problem: this is not necessarily right... The task is to imagine methods when they no longer seek the definite, the repeatable, the more or less stable. When they no longer assume that this is what they are after. (p. 6)

In Law's (2004) view, researchers need to research practices that bring methods to the realms of localities, specificities, enactments, multiplicities, fractionalities, resonances, gatherings, dances, imaginaries, passions, and interferences. He asks how do we account for a world thought as "filled with currents, eddies, flows, vortices, unpredictable changes, storms, and with moments of lull and calm" (p.7). The task, he says, is "to begin to imagine what research methods might be if they were adapted to a world that included and knew itself as tide, flux, and general unpredictability" (p.7).

We also turn toward scholarship that calls for methodologies that engage with "more-than-socially constructed worlds" (Greenhough, 2012, p. 204). For instance, Haraway's work $(1991,1997,2008)$ troubles objective anthropocentric reality and 
points to the importance of research that attends to the pastpresent entanglements of histories and the complex more-than-human relationalities and multiplicities of contingent events and encounters. This suggests a need for research practices and concepts that are "not reducible to discourse or representation, for they are modes of resonance or vibration, modes of connection or disconnection, 'movable bridges' between other concepts and, above all, to events" (Grosz, 2010, p. 99). Here research, rather than being a site for representation, is a politically situated practice that is embedded in rhizomatic power relations (Deleuze \& Guattari, 1987) where questions of ontology and ethics matter to "world-making entanglements" (Haraway, 2008, p. 4).

Such methodologies reconfigure research and the researcher as affective-relational-located-responsible-accountable-noninnocent-implicated in practices of knowledge-making (Haraway, 1997). These methodologies figure relationality, uncertainty, contingency, and partiality as central to the ways in which contingent becoming-with the world is envisaged (Haraway, 2008). Research as knowledgemaking and world-making unsettles dominant assumptions about the authority to produce knowledge about the world, unsettles monolithic visions of knowledge, unsettles the neutrality and immateriality of knowledge, and troubles borders and categories, including the boundaries between subject and object (Haraway, 1991, 2008, 2011). This work points to methodologies that inhabit power relations and make a difference (Haraway, 2011). Such research creates interferences and disruptions to the exteriorities claimed by colonizing research practices that "teach that knowers are manipulators who have no reciprocal responsibilities to the things they manipulate" (Battiste \& Henderson, 2000, p. 88).

As another example, we find potential in the methodological approach proposed by Kathleen Stewart (2008). She suggests ethnographic research that centers attentiveness to the social and cultural forces within which the intricacies, contradictions, seeming banalities, and affective textures of everyday encounters are composed. This is a process that attends to things in the middle. She writes:

Things that have impact. Things caught in a circuit of action and reaction. Not simple or self-contained things, but things like the way the senses literally jump in moments of spacing out or ducking for cover, or the sad sagging of trajectories that held promise just a minute ago, or the serial build-up of the sense of being in one thing and then another. (p. 71)

In her work, rather than following a predefined methodological path, Stewart is interested in a methodology that becomes "unstuck from its own line of thought 
to follow the objects it encounters, or becomes undone by its attention to things that don't just add up but take on a life of their own as problems for thought" (p. 72).

A methodology that becomes unstuck from itself does not seek to define, analyze, and categorize but instead describes "the moment itself when an assemblage of discontinuous yet mapped elements throws itself together into something" (Stewart, 2008, p. 73). In this "weak methodology," as Stewart (2008) calls it, the goal is not to provide a representation of something "but to wonder where (analytic objects) might go and what potential modes of knowing, relating, and attending to things are already somehow present in them as a potential or resonance" (p. 74). This methodology attends to encounters through which connections, trajectories, potentialities, and tensions emerge that exceed their description, yet make visible a situated politics that attends to the inequities produced by neoliberalism on their contingent and creative effects in everyday life. Such a methodology transgresses the limits imposed by deterministic representations while attending to the marginalizing effects and tensions in the social relations it encounters.

Barad's (2007) agential realism, specifically her intra-activity framework, has also helped us to understand the entangled process of transformation that takes place in the world and to rethink our research practices in the slippery territories of neoliberalisms and neocolonialisms. She speaks about intra-action as signifying

the mutual constitution of entangled agencies. That is, in contrast to the usual 'interaction', which assumes that there are separate individual agencies that precede their interaction, the notion of intra-action recognizes that distinct agencies do not precede, but rather emerge through, their intra-action. It is important to note that the 'distinct' agencies are not only distinct in a relational, not an absolute, sense, that is, agencies are only distinct in relation to their mutual entanglement; they don't exist as individual elements. (p. 33)

Barad highlights the productive aspects of relations. In contrast to the usual understanding of interaction, which assumes separateness and individual agency of physical matter, the idea of intra-action proposes that distinct agencies of matter emerge through their intra-action; in their mutual entanglement, they do not even exist as individual elements. Thus it is through intra-action that particular material articulations of the world become meaningful.

Following Barad's (2007) agential realism, several questions arise that might be important for engaging with neoliberal assemblages: How do neoliberal assemblages work? What kinds of work do neoliberal assemblages do? What role do neoliberalisms and neocolonialisms play in operating and producing early childhood practices? 
What role do neoliberal assemblages play in reconfiguring neocolonial boundaries and relations? What sort of temporalities do neoliberal assemblages engender? What sort of shifts in assemblages do neoliberalisms and neocolonialisms encourage? How are specific practices of early childhood education mediated by neoliberalisms and neocolonialisms? Do neoliberalisms and neocolonialisms in diverse spaces do different work and engender varying practices and relations? How do neoliberalisms and neocolonialisms always emerge differently?

These approaches to research that engage with the complexities of the world provide opportunities for us to engage in "researching" neoliberalism as a complicated assemblage. The work we have reviewed in this section of the paper has inspired our "researching." Yet, we acknowledge that our preliminary attempts are only beginnings to the possibilities that this body of work presents to researchers of neoliberalisms.

\section{Researching Neoliberal and Neocolonial Assemblages: Examples for Critical Qualitative Research}

Working with the concept of assemblages has allowed us to find unexpected sites and connections from which to interrogate colonialisms in relation to neoliberalism. Coloniality is figured strongly in present conditions through "persistent 'neo-colonial' relations" (Bhabha, 1994, p. 9). As Stoler (2011) points out, "in new force fields [colonialisms] are reactivated unevenly and strategically and are part of the fabric that shapes the liveliness of racialized ascriptions and the lividness of the affective states tied to them" (p. 156). In this section we address neoliberal assemblages in relation to neocolonialisms and show, through four different examples, how we have engaged in researching these assemblages.

Using Cross-disciplinary Engagement to Unmask Silenced Histories. Our first example shows how we have drawn from the arts to research the complex connections between neoliberal assemblages and colonialisms. We began with a "usual" moment in a child care centre in Northern Canada: lunch time (PaciniKetchabaw, Nxumalo \& Rowan, 2011). We then drew on the work of Brian Jungen, a Vancouver artist, to create unexpected connections. Instead of presenting objects "as they are," Jungen reworks them without fully concealing their original meaning or purpose. For example, he has turned white plastic chairs into the skeleton of a whale and suspended it in the air. He has taken apart Nike Air shoes and restitched them into First Nations masks and fashioned totem poles from high-end golf bags (Off, 2009). Jungen disassembles and then reassembles objects in new ways so the viewer 
of his art can recognize the source object while opening to new meanings, often indefinable ones. We drew on Jungen's work to show how colonialism can function as a part of neoliberal assemblages in everyday moments at a child care centre (Pacini-Ketchabaw et al., 2011). We have found that interesting questions emerge when we place Jungen's work alongside everyday encounters in child care centres that connect to racialization and colonialisms (Pacini-Ketchabaw et al., 2011). Some of the methodological questions we have asked in juxtaposing Jungen's work against these encounters include: What do these assemblages do together? How do they function? What possibilities do they provoke? How does racism and colonialism get interrupted as these assemblages come together to form a new assemblage? In this way, we attempt to create productive spaces for making our data stutter against neoliberalisms, racisms, and colonialisms (Pacini-Ketchabaw et al., 2011).

We are also interested in how histories act upon and shift present-day racisms and neocolonialisms. Silences on racialized and colonial inequities shift discussions of the socioeconomics of racism and neocoloniality out of public political discourse "and reassign identity-based biases to the private and personal spheres" (Davis, 2007, p. 349). Neoliberal postracial worldings, then, can be seen as enactments through which historical racisms and colonialisms are continually reinforced and revitalized in new and, often, subtle ways (Goldberg, 2008). The capriciousness and contradictions of neoliberal assemblages also obscure racisms, not only through the discourse of postraciality but in certain contexts through a discourse of anti-racism, whereby anti-racism is a stated value, as in discourses of tolerance and inclusiveness. However, within these neoliberal assemblages, racialized inequalities are normalized and intensified by neoliberal policies (Goldberg 2008; Shire 2008).

Often times an assemblage masks neoliberal alignments with systemic inequities through a privatization or marketization whereby "racisms proliferate in the reductive impossibility of being recognized as precisely racist... building silently on the structural conditions of racism while evaporating the very categories of their recognizability" (Goldberg, 2008, p. 1715). The persistence of racisms and colonialisms that limit the capacities of certain bodies appears to contradict neoliberal discourses of equal opportunity, freedom, or free agency. These contradictions of neoliberal formations, including the shifting and contradictory ways in which race comes to matter within neoliberal assemblages, make it difficult to ascertain neoliberalism's role as an active participant in the mobilization and sedimentation of racisms and colonialisms.

The entanglements of neoliberal assemblages with neocolonialisms are made even more difficult to ascertain by the mobilities, complexities, and contingencies 
of neocolonialisms themselves. In what is now Canada, we are immersed in "shapeshifting colonial" spatio-temporalities (Alfred \& Corntassel, 2005, p. 601) that take on different, often subtle forms in assembling technologies of control, attaching to things, bodies, places and policies, systems, and structures (Deleuze, 1992). The "colonial order of things" (Stoler, 2008, p. 193) endures and takes on new forms such as in its social, political, and everyday entanglements with, for instance, government policies, racialized and gendered labour, migration, globalization, capital neoliberalism, monolithic representations of (neo)colonial subjects, and Eurocentric hegemonies of knowledge (Alexander, 2005; Bhabha, 1994; Gilroy, 2005; Mohanty, 1991, 2003, 2007; Stoler, 2008; Subedi \& Daza, 2008).

Examining Human/Nonhuman Entanglements. The spatialized effects of colonialism endure through ongoing appropriation of territories, the spatial ordering of racialized and colonized bodies, and violent cuts to the more-than-human connections between Indigenous land and dignity. Difference, diversity, cultures, and languages are continually territorialized, appropriated, and commodified through their entanglements with neoliberal assemblages (Braidotti, 2005). The entrenched forces of racist colonial legacies collide with other political, neoliberal, material, affective, attitudinal, systemic, discursive, and contextual forces in everyday relational encounters and have an impact on processes of subjectification-on human and nonhuman bodies' capacity to act (Ausch, Doane, \& Perez, 2001).

By looking at human-nonhuman entanglements, we have argued that the troubling of neoliberalism and colonialisms is not limited to humans (Nxumalo, 2012; Pacini-Ketchabaw, 2012). For example, by mapping relations between indigenous deer and settler Canadians, and situating this mapping in the specific relations and entanglements of the lives of young children and their encounters with deer on Vancouver Island, we have illustrated the importance of analyses of neocolonial and neoliberal entanglements that consider all partners and relational knots (PaciniKetchabaw, 2012). In this specific example, we have considered how fences, children, and deer form neocolonial and neoliberal assemblages within the colonized and colonialist spaces where deer and human children "meet." The province of British Columbia, which is home to mule deer, employs narratives of unspoiled wilderness in ways that work to serve the ongoing colonial project (Braun, 2002) while urban and industrial encroachment into deer's habitats continues. The deer who look at us (and we who look at the deer) are part of colonial conquest, trade, neoliberal economies, ecologies, resistances, tourism, and entertainment (Haraway, 2008).

Paradoxically, alongside the constraining effects of neoliberalism and its control of flows and constraints of bodies, neoliberal forces seem to expand possibilities, 
acting at the level of what is seen as desirable (Deleuze, 1992; Ren, 2005). For example, individual choice and responsibility are seen as desirable, and neoliberal subjects thereby appear self-governing through the "freedom" to choose to act in particular ways and become responsible for their own acts (Ren, 2005). However, the persistence of neocolonialisms that limit the capacities of certain bodies, whether identified as human or nonhuman, appears to contradict neoliberal discourses of equal opportunity, freedom, or free agency. Through mobility, contingency, and flexibility, neoliberalisms can "stick" together to produce dangerous effects for/on the capacities of certain bodies and not others.

Mapping Everyday Spaces. As we have been taking into consideration the challenges of qualitative research, our approach to engaging with neoliberal and neocolonial assemblages has been through the mapping elements and intra-actions of everyday assemblages in early childhood education spaces. Through our mapping, we have not attended to a grand narrative of the workings of neoliberalism. Instead we have followed Braidotti's (2011) cartographic mapping. She says that what she writes are cartographies or "maps of positioning," "a sort of intellectual landscape gardening that gives" her "a horizon, a frame of reference within which" she can take her "bearings, move about, and set up" her "own theoretical tent" (p. 46).

For example, we have mapped the Inuit early childhood education-food-eating assemblage (Nxumalo et al., 2011) to examine connections, tensions, and disjunctures between visceral everyday encounters, government regulations, and particular sociopolitical and historical moments. Through this mapping we have attempted to engage with power production from visceral-political perspectives (A. Hayes-Conroy \& J. Hayes-Conroy, 2008; A. Hayes-Conroy \& Martin, 2010; Probyn, 2000; Whatmore, 2002) with the emergence and workings of neoliberal rationalities (Guthman, 2008) and with the circulations of neocolonialism at an intimate corporeal level (Slocum, 2008, 2011). We have made visible how the emergence of individualized neoliberal subjectivities effectively occludes the convergence of histories and present-day constraints that impact how people can extricate themselves from the persistent neocolonial "order of things" (Stoler, 2008, p. 193). By attending to how neoliberal rationalities and mentalities work as rhizomatic, contradictory, and mobile assemblages, we have "cracked open" eating and feeding routines in Inuit early childhood education by making them function alongside neoliberalism and, more poignantly, in connection with racialization and neocolonization.

By conceptualizing neoliberalisms as assemblages, we have been able to pay particular attention to the mundane, to our situated positions, and to the ordinary in our mapping. Following Stewart (2007), we have presented an (unstable) assemblage 
through a series of ordinary affects. That is, we attended to the intensities of certain encounters, to disparate connections, and to everyday sites and situations that link to neoliberalism and neocolonialism assemblages. Our emphasis has been on the multiple linkages or interconnections between key elements of a particular assemblage and the effects produced by the intermingling of these elements within our geopolitical context and the broader context of the forces of neoliberal and neocolonial assemblages.

Our attention to a particular geopolitical context, Nunavik in Quebec, has been a way of engaging with the disparate ways in which neoliberal assemblages are constantly becoming:

Neoliberalism is a spatial project that is spatially projected because, despite the rhetoric of how neoliberal globalization is purportedly producing a flat and borderless world in which distance and geography no longer matter, the sway of place still shapes how political praxis is imagined and articulated in these neoliberal times-the histories of social struggles and their institutional memories are very much tied up in the spatialities of the global economy and greatly influence how neoliberalism is being implemented locally and nationally. (Herod \& Aguiar, 2006, p. 435)

Our intent has been to flesh out the elements of the assemblage, to show their mobile, contradictory, rhizomatic character. We have also attempted to move away from "representation" (Law, 2004) toward the production of affects. In our writings, we invite the reader to consider the workings of the assemblage with respect to the affects, technologies, bodies, flows, visualizations, and power relations that conjoin to both create and emerge from the assemblage (Stewart, 2007). For instance, one might consider the ordering of bodies according to policies and practices that act, often in subtle and hidden ways, to inscribe, categorize, stabilize, and, simultaneously, open up particular subjectivities while privileging certain political, social, and economic systems or structures.

The elements we concentrate on in mapping the assemblage include a range of discursive and material mechanisms of surveillance and control that attempt to affect specific early childhood arrangements and that act to affect and appropriate subjectivities (Haggerty \& Ericson 2000; Patton 1994). For instance, we have juxtaposed an ordinary lunch time moment in an Inuit child care centre, food regulations in Inuit child care, colonial histories of residential schooling, the denigration of hunter gatherers, hunger in Inuit communities, and health consequences of a Western diet for Inuit communities, among other social and other contemporary food-eating 
encounters. Importantly, by tracing connections between diverse entities such as the caribou, the food guide for First Nations and Inuit, polluted Northern territories, and lunch time at the child care centre, we have made visible the complexities of heterogeneous neoliberal relations, where the human is "no less a subject of ongoing cofabrication than any other socio-material assemblage" (Whatmore, 2006, p. 603; see also Haraway, 2008).

We wonder about how colonialisms and racisms act through the appropriation of bodies in our data of feeding practices in the Inuit early childhood classroom. What emerges in this assemblage? What emerges in the assemblage educator-childspoon-food-table and more? How does the spoon come to matter in the very act of colonialism? How do the plates matter? How does the table matter? How are the tables, plastic chairs, metal spoons, and their configurations in the room all active participants in food-eating practices as colonial acts? How might we reconsider the workings of neocolonialisms and racialization through everyday food-eating practices (Slocum, 2011)? How do these fragments perpetuate or disrupt forces of racism and colonialism (Pacini-Ketchabaw et al., 2011)?

Through our mapping, we have presented neoliberal and neocolonial assemblages as always partial and selective conceptualizations of immensely complex, intrinsically elusive, and constantly forming modes and technologies of control in the domain of early childhood education. In addition, in our mappings, we have seen early childhood as more than the practices that occur within its confines. These processes speak to our intention to move beyond (over)simplified research claims. There are always things/processes/discourses/materialities at work that are not necessarily mapped. Yet, through our mappings we were able to highlight the contradictory and capricious ways in which neoliberalism can present itself in Inuit early childhood spaces through a multiplicity of processes, regulations, and actions that are always already racialized and colonized.

Researching Policy Assemblages as Actants. Our last example comes from our current work. We are engaged in mapping how concepts such as "recognition," "diversity," "acceptance," and "inclusion" of the Other emerge and assemble together in early childhood education through policy. Following the work of Law (2004), Latour (1996), and Prior (2008), we are "analyzing" neoliberal policy documents and nongovernmental organization guides to inclusion (e.g., Early Childhood Research and Development Team, 2008; Government of British Columbia, 2008; Joint First Nations/Inuit/Federal Child Care Working Group, 1995; Nabavi, 2011) that have been published in Canada and which we take up as actants (Latour, 1996). Latour (1996) argues that thinking about actants creates shifts away from anthropocentric 
perspectives, noting that "actant implies no special motivation of human individual actors, nor of humans in general" (p. 373). An actant, Latour says, "can literally be anything provided it is granted to be the source of an action" (p. 373). Conceptualizing policy documents as actants creates shifts from individualist and static perspectives where they "are not conceived as fixed entities but as flows, as circulating objects, undergoing trials, and their stability, continuity, isotopies has to be obtained by other actions and other trials" (p. 374), creating more possibilities for addressing neoliberalisms and neocolonialisms on their slippery territories.

In the Canadian context, these policy documents and guides are presented as innovative and transformational because they respond to calls for diversity and equity in the field of early childhood. We want to unpack these conceptualizations. Therefore, our goal is to work with these documents beyond their specific content and instead pay attention to how they form assemblages and connect to neoliberal and neocolonial assemblages. We are interested in looking at these actants as part of a field that function in a network of actions (Prior, 2008). We are interested in moving from paying attention to "matters of fact" to addressing "matters of concern." As Latour (2008) notes, "A matter of concern is what happens to a matter of fact when you add to it its whole scenography, much like you would do by shifting your attention from the stage to the whole machinery of a theatre" (p. 39). Latour (2004) continues:

Matters of fact are not all that is given in experience. Matters of fact are only very partial and, I would argue, very polemical, very political renderings of matters of concern and only a subset of what could also be called states of affairs. (p. 232)

Again, we hope that through these methodological moves, we begin to attend to the complexities instead of trying to simplify the workings of neoliberalisms and neocolonialisms.

Our analysis of these texts follows Prior's (2008) work. He emphasizes "how documents as 'things' function in schemes of social activity, and with how such things can drive, rather than be driven by, human actors - i.e. the spotlight is on the vita activa of documentation" (p. 826). Rather than a sole focus on the content of documents (for example, through discourse analysis), this approach enables a consideration of how documents become configured in and reconfigure neoliberal assemblages; how they function as "props, allies, rule-makers, calculators, decisionmakers, experts, and illustrators"; how they shape subjectivities; and how they participate in making, mediating, and performing certain knowledges and relations 
while limiting others-often in ways that are not a direct intent of the authors (p. 828). Methodologically then, this approach necessitates attention to not only to what documents say but what documents $d o$ within their material-discursive relationalities both as a constituent part of and active in the making of neoliberal and neocolonial assemblages (Nimmo, 2011; Prior, 2008).

Some of the questions we are asking of these documents in relation to their mobile and sociomaterial entanglements within neoliberal and neocolonial assemblages include: What does diversity do? What does recognition do? What does inclusion do? What does acceptance do? What do these knowledges do in relation to the formation of neoliberal assemblages, more specifically in relation to constructions and inscriptions of the desirable "diverse" subject? How are these knowledges positioned within neoliberal and neocolonial assemblages in the context of early childhood education in Canada? Encountering documents from these perspectives also enables their implication in practices. For instance, we are attending to the following questions: What knowledge is generated about early childhood education practice through the language of diversity, recognition, acceptance, and inclusion? How do these documents assemble, mold, and create linkages between practices (Nimmo, 2011)? How do they "enact objects, constitute subjects, and inscribe relations, ontological boundaries and domains" (Nimmo, 2011, p. 114)? How do "acceptance," "inclusion," "diversity," and "recognition" (assembled together) act in the emergence of desirable (diverse/cultural) neoliberal subjects? What does the "neoliberal and neocolonial subject of diversity" do with(in) early childhood education?

The examples we have discussed suggest that the complexity, fluidity, and entanglements of neoliberal and neocolonial formations point to the need for methodological tools that examine the intimate connections between neoliberalisms and colonial legacies. How do they come together, act, and nourish each other to mobilize neocolonial relations and practices? These complexities suggest seeking methodological approaches that create openings to engage critically with the manner in which neocolonialisms and neoliberalisms work multifariously, paradoxically, and at times ambivalently, and not necessarily in rational, predictable ways.

In attending to the challenges of researching neoliberalisms and neocolonialisms in early childhood education, we attended to emergent, interconnected entanglements of relationships within assemblages of material-discursive forces (Ong, 2007). We asked about neoliberalisms and neocolonialisms and what they do, and queried effects produced through the spacialized ordering of colonized bodies and the disruption of relationships between humans and lands. These questions and queries required us to think about research differently and to move beyond insufficient rules and processes 
and away from representation (Law, 2004). We discounted limiting expectations and engaged with weak theories (Stewart, 2008). Through this emerging methodology, we seek news ways of becoming with early childhood spaces.

\section{References}

Alexander, M. J. (2005). Pedagogies of crossing: Meditations on feminism, sexual politics, memory, and the sacred. Durham, NC: Duke University Press.

Alfred, T., \& Corntassel, J. (2005). Being Indigenous: Resurgences against contemporary colonialism. Government \& Opposition, 40, 597-614.

Anderson, B., \& McFarlane, C. (2011). Assemblage and geography. Area, 43, 124-127. doi:10. $1111 / \mathrm{j} .1475-4762.2011 .01004 . \mathrm{x}$

Ausch, R., Doane, R., \& Perez, L. (2001). Interview with Elizabeth Grosz. Found Object, 9, 1-16. Retrieved from http://web.gc.cuny.edu/csctw/found_object/text/grosz.htm

Baldwin, A., Cameron, L., \& Kobayashi, A. (2011). Where is the Great White North? Spatializing history, historicizing whiteness. In A. Baldwin, L. Cameron, \& A. Kobayashi (Eds.), Rethinking the Great White North: Race, nature and the historical geographies of whiteness in Canada (pp. 1-15). Vancouver: University of British Columbia Press.

Barad, K. (2007). Meeting the universe halfway: Quantum physics and the entanglement of matter and meaning. Durham, NC: Duke University Press.

Battiste, M., \& Henderson, J. Y. (2000). Protecting Indigenous knowledge and heritage: A global challenge. Saskatoon, SK: Purich.

Bhabha, H. K. (1994). The location of culture (2nd ed.). London: Routledge.

Braidotti, R. (2005). A critical cartography of feminist post-postmodernism. Australian Feminist Studies, 20, 169-180. doi:10.1080/08164640500090319

Braidotti, R. (2011). Nomadic subjects: Embodiment and sexual difference in contemporary feminist theory (2nd ed.). New York: Columbia University Press.

Braun, B. (2002). Colonialism's afterlife: Vision and visuality on the Northwest Coast. Cultural Geographies, 9, 202-247. doi:10.1191/1474474002eu242oa

Collier, S. J. (2012). Neoliberalism as big leviathan, or... ? A response to Wacquant and Hilgers. Social Anthropology/Anthropologie Sociale, 20, 186-195. doi:10.1111/j.14698676.2012.00195.x

Davis, D.-A. (2007). Narrating the mute: Racializing and racism in a neoliberal moment. Souls: A Critical Journal of Black Politics, Culture, and Society, 9, 346-360. doi:10.1080/ 10999940701703810

Deleuze, G. (1992). Postscript on the societies of control. October, 59, 3-7.

Deleuze, G., \& Guattari, F. (1987). A thousand plateaus: Capitalism and schizophrenia (B. Massumi, Trans.). Minneapolis: University of Minnesota Press.

Early Childhood Research and Development Team. (2008). New Brunswick curriculum framework for early learning and child care-English. Fredericton, NB: Department of Social Development. Retrieved from http://www.gnb.ca/0000/ECHDPE/curriculum-e.asp

Edwards, R. (2012). Theory matters: Representation and experimentation in education. Educational Philosophy and Theory, 44, 522-534. doi:10.1111/j.1469-5812.2010.00719.x

Gilroy, P. (2005). Postcolonial melancholia. New York: Columbia University Press.

Goldberg, D. T. (2008). Racisms without racism. PMLA, 123, 1712-1716. doi:10.1632/pmla. 2008.123.5.1712 
Government of British Columbia. (2008). British Columbia early learning framework. Victoria, BC: Ministry of Education, Ministry of Health, Ministry of Children and Family Development. Retrieved from http://www.bced.gov.bc.ca/early_learning/pdfs/early_ learning_framework.pdf

Greenhough, B. (2012). On the agencement of the academic geographer. Dialogues in Human Geography, 2, 202-206. doi:10.1177/2043820612449296

Grosz, E. (2010). The practice of feminist theory. Differences: A Journal of Feminist Cultural Studies, 21(1), 94-108. doi:10.1215/10407391-2009-019

Guthman, J. (2008). Neoliberalism and the making of food politics in California. Geoforum, 39, 1171-1183. doi:10.1016/j.geoforum.2006.09.002

Haggerty, K. D., \& Ericson, R. V. (2000). The surveillant assemblage. The British Journal of Sociology, 51, 605-622. doi:10.1080/00071310020015280

Haraway, D. J. (1991). Simians, cyborgs, and women: The reinvention of nature. New York: Routledge.

Haraway, D. J. (1997).Modest_witness@second_millenium.FemaleMan@_meets_OncoMouse TM: Feminism and technoscience. London: Routledge.

Haraway, D. J. (2008). When species meet. Minneapolis: University of Minnesota Press.

Haraway, D. J. (2011). Playing cat's cradle with companion species: The Wellek lectures. Retrieved from http://people.ucsc.edu/ haraway/

Hayes-Conroy, A., \& Hayes-Conroy, J. (2008). Taking back taste: Feminism, food and visceral politics. Gender, Place and Culture, 15, 461-473. doi:10.1080/09663690802300803

Hayes-Conroy, A., \& Martin, D. G. (2010). Mobilising bodies: Visceral identification in the Slow Food movement. Transaction of the Institute of British Geographers, 35, 269-281. doi:10.1111/j.1475-5661.2009.00379.x

Herod, A., \& Aguiar, L. L. M. (2006). Geographies of neoliberalism. Antipode, 38, 435-439. doi: 10.1111/j.0066-4812.2006.00588.x

Hier, S. P. (2003). Probing the surveillant assemblage: On the dialectics of surveillance practices as processes of social control. Surveillance \& Society, 1, 399-411.

Joint First Nations/Inuit/Federal Child Care Working Group. (1995). Considerations for the First Nations/Inuit Child Care Program and funding framework: Technical report. Ottawa, ON: Human Resources Development Canada.

Kalb, D. (2012). Thinking about neoliberalism as if the crisis was actually happening. Social Anthropology/Anthropologie Sociale, 20, 318-330. doi:10.1111/j.1469-8676.2012. 00215.x

Koro-Ljungberg, M., \& Mazzei, L. A. (2012). Problematizing methodological simplicity in qualitative research: Editors' introduction. Qualitative Inquiry, 18, 728-731. doi:10. $1177 / 1077800412453013$

Latour, B. (1996). On actor-network theory: A few clarifications. Soziale Welt, 47, 369-381.

Latour, B. (2004). Why has critique run out of steam? From matters of fact to matters of concern. Critical Inquiry, 30, 225-248.

Latour, B. (2008). What is the style of matters of concern? Two lectures in empirical philosophy. Spinoza Lectures at the University of Amsterdam, April and May 2005, Van Gorcum Amsterdam: University of Amsterdam. Retrieved from http://www.bruno-latour.fr/sites/ default/files/97-SPINOZA-GB.pdf

Law, J. (2004). After method: Mess in social science research. London: Routledge.

MacLure, M. (2010). The offence of theory. Journal of Education Policy, 25, 277-286. doi:10. 1080/02680930903462316 
Mazzei, L. A., \& McCoy, K. (2010). Thinking with Deleuze in qualitative research. International Journal of Qualitative Studies in Education, 23, 503-509. doi:10.1080/ 09518398.2010.500634

McCoy, K. (2012). Toward a methodology of encounters: Opening to complexity in qualitative research. Qualitative Inquiry, 18, 762-772. doi:10.1177/1077800412453018

Mohanty, C. T. (1991). Under Western eyes: Feminist scholarship and colonial discourses. In C. T. Mohanty, A. Russo, \& L. Torres (Eds.), Third world women and the politics of feminism (pp. 51-80). Bloomington: Indiana University Press.

Mohanty, C. T. (2003). Feminism without borders: Decolonizing theory, practicing solidarity. Durham, NC: Duke University Press.

Mohanty, C. T. (2007). Anti-capitalist feminist struggle, and transnational solidarity: An interview with Chandra Talpade Mohanty [Video file]. Retrieved from http://vimeo.com/ 28572566

Mol, A. (2002). The body multiple: Ontology in medical practice. Durham, NC: Duke University Press.

Nabavi, M. (2011, October). "Promising practices" of early childhood education for immigrant and refugee children in British Columbia. Vancouver, BC: Affiliation of Multicultural Societies and Service Agencies of BC. Retrieved from http://www.ecebc.ca/news/ AMSSA_Promising_Practices.pdf

Nimmo, R. (2011). Actor-network theory and methodology: Social research in a more-thanhuman world. Methodological Innovations Online, 6(3), 108-119. doi:10.4256/mio.2011. 010

Nxumalo, F. (2012). Unsettling representational practices: Inhabiting relational becomings in early childhood education. Child \& Youth Services, 33, 281-302. doi:10.1080/0145935X. 2012.745783

Nxumalo, F., Pacini-Ketchabaw, V., \& Rowan, M. C. (2011). Lunch time at the child care centre: Neoliberal assemblages in early childhood education. Journal of Pedagogy, 2, 195-223. doi:10.2478/v10159-011-0010-4

Off, C. (2009, October 21). Brian Jungen [Audio podcast]. CBC Radio. Retrieved from http:// www.cbc.ca/asithappens/features/2009/10/21/brian-jungen/

Ong, A. (2007). Neoliberalism as a mobile technology. Transactions of the Institute of British Geographers, 32, 3-8. doi:10.1111/j.1475-5661.2007.00234.x

Pacini-Ketchabaw, V. (2012). Postcolonial entanglements: Unruling stories. Child \& Youth Services, 33, 303-316. doi:10.1080/0145935X.2012.745790

Pacini-Ketchabaw, V., Nxumalo, F,. \& Rowan, C. (2011). Nomadic research practices in early childhood: Interrupting racisms and colonialisms. Reconceptualizing Educational Research Methodology, 2(1), 19-33.

Patton, P. (1994). Metamorphologic: Bodies and powers in a thousand plateaus. Journal of the British Society for Phenomenology, 25(2), 157-169.

Peck, J., \& Theodore, N. (2012). Reanimating neoliberalism: Process geographies of neoliberalisation. Social Anthropology/Anthropologie Sociale, 20, 177-185. doi:10.1111/j.14698676.2012.00194.x

Prior, L. (2008). Repositioning documents in social research. Sociology, 42, 821-836. doi:10. $1177 / 0038038508094564$

Probyn, E. (2000). Carnal appetites: Food sex identities. New York: Routledge.

Ren, H. (2005). Modes of governance in neo-liberal capitalism: An introduction. Rhizomes,10. Retrieved from http://www.rhizomes.net/issue10/introren.htm 
Shire, G. (2008). Race in neoliberal times. Soundings: A Journal of Politics and Culture, 38, $70-81$.

Slocum, R. (2008). Thinking race through corporeal feminist theory: Divisions and intimacies at the Minneapolis farmers' market. Social \& Cultural Geography, 9, 849-869. doi:10. $1080 / 14649360802441465$

Slocum, R. (2011). Race in the study of food. Progress in Human Geography, 35, 303-327. doi: $10.1177 / 0309132510378335$

Stewart, K. (2007). Ordinary affects. Durham, NC: Duke University Press

Stewart, K. (2008). Weak theory in an unfinished world. Journal of Folklore Research, 45, $71-82$.

Stoler, A. L. (2008). Imperial debris: Reflections on ruins and ruination. Cultural Anthropology, 23, 191-219. doi:10.1111/j.1548-1360.2008.00007.x

Stoler, A. L. (2011). Colonial aphasia: Race and disabled histories in France. Public Culture, 23, 121-156.

Subedi, B., \& Daza, S. L. (2008). The possibilities of postcolonial praxis in education. Race, Ethnicity and Education, 11, 1-10. doi:10.1080/13613320701845731

Whatmore, S. (2002). Hybrid geographies: Natures cultures spaces. London: Sage.

Whatmore, S. (2006). Materialist returns: Practicing cultural geography in and for a morethan-human world. Cultural Geographies, 13, 600-609. doi:10.1191/1474474006cgj377oa

\section{About the Authors}

Veronica Pacini-Ketchabaw is a professor at the School of Child \& Youth Care at the University of Victoria, Canada, and has worked professionally in the field of early childhood education for more than 20 years both in Canada and Argentina. Her scholarship focuses on rethinking and reimagining early childhood education from theoretically and philosophically informed standpoints rooted in feminist, (post)colonial, antiracist, and posthumanist perspectives.

Fikile Nxumalo is a doctoral candidate at the University of Victoria in Canada. The aim of her research is to bring posthumanist theories, Indigenous relationalities, and postcolonial perspectives into conversation, with a focus on possibilities for anticolonial and antiracist responses to everyday encounters in settler-colonial early childhood spaces. Methodologically, the research experiments with refiguring presences through stories of human-nonhuman entanglements.

Mary Caroline Rowan is a doctoral candidate at the University of New Brunswick, Canada. Her research engages with Inuit educators, Elders, families, and children in co-constructing place-based approaches to early childhood education in Nunavik, Canada. The research adopts a storying methodology informed by Indigenous research methodologies. This project particularly highlights scholarship in circumpolar places. 